\title{
PELUANG DAN TANTANGAN ARSITEKTUR DALAM INDIKATOR TEMATIK BUDAYA, AGENDA 2030
}

\author{
Dina Poerwoningsih* dan Imam Santoso \\ Program Studi Arsitektur, Fakultas Teknik, Universitas Merdeka Malang \\ *dina.poerwoningsih@unmer.ac.id
}

\begin{abstract}
ABSTRAK
Tulisan ini dimaksudkan untuk melihat peluang dan tantangan arsitektur di era SDGs-2030 ini. Salah satunya dengan pendekatan keterkaitan dan hubungan arsitektur dan budaya. Salah satu alasan eksternal adalah baru di era SDGs-2030 inilah budaya mendapatkan pengakuan dan tempat sebagai penentu perubahan dunia. Hidup di dunia yang terglobalisasi adalah sebuah keniscayaan, oleh karenanya diperlukan pola pikir global dalammenghadapi tantangan dan realitas global tersebut. Demikian pula semestinya dalam cara dan pola pikir kita pelaku akademis dan praktisi bidang arsitektur di era tersebut. Isu Agenda 2030 mewarnai ekonomi dan budaya di Indonesia dengan berkembangnya industri kreatif dan ekonomi kreatif, dimana arsitektur menjadi salah satu sub sektor kreatif menurut BEKRAF. Tulisan ini bertujuan menyampaikan eksistensi peluang dan tantangan arsitektur di era SDGs-2030 khusunya dalam tema budaya. Strategi yang dilakukan adalah membaca peluang dalam isu-isu utama Agenda 2030 yang tertuang dalam sebuah konvensi Culture 2030 Indicator. Penelitian yang mendukung tulisan ini bersifat deskriptif eksploratif. Sejumlah 22 poin konvensi dalam tema budaya yang terdapat pada 4 isu utama Agenda 2030 digunakan sebagai alat utama analisis. Sementara itu klasifikasi bidang atau kegiatan arsitektur diperlukan untuk melihat bobot peluang dan tantangan yang berbeda-beda. Analisis dilakukan secara interpretatif terhadap setiap poin konvensi dalam keterkaitannya dengan setiap klas kegiatan arsitektur.
\end{abstract}

Keywords: Indikator Tematik Budaya, Agenda 2030, Arsitektur dan Budaya

\begin{abstract}
This paper is intended to look at architectural opportunities and challenges in the era of SDGs-2030. One of them is the approach to interconnection and the relationship between architecture and culture. One of the external reasons is that it was only in the SDGs-2030 era that culture gained recognition and place as a determinant of world change. Life in a globalized world is a necessity, therefore we need a global mindset in dealing with these global challenges and realities. Likewise, in the manner and mindset of us, academics and practitioners of architecture in that era. The 2030 Agenda issue colors the economy and culture in Indonesia with the development of the creative industry and creative economy, where architecture is one of the creative sub-sectors according to BEKRAF. This paper aims to
\end{abstract}


convey the existence of architectural opportunities and challenges in the era of SDGs-2030 especially in cultural themes. The strategy taken is to read opportunities in the main issues of the 2030 Agenda that set out in a Culture 2030 Indicator convention. Research supporting this paper is exploratory in nature. A total of 22 convention points on cultural themes on the 4 main issues of the 2030 Agenda are used as the main tools of analysis. Meanwhile the classification of fields or architectural activities is needed to see the weight of different opportunities and challenges. The analysis is interpretive to each convention point in relation to each class of architectural activities.

\section{Keywords: Thematic Indicators of Culture, Agenda 2030, Architecture and Culture}

\section{PENDAHULUAN}

Di era SDGs-2030, cara pandang terhadap semua aspek persoalan kehidupan manusia menjadi semakin terbuka dan transparan. Telah banyak contoh-contoh yang menunjukkan bahwa dunia kita semakin terglobalisasi. Hidup di dunia yang terglobalisasi adalah sebuah keniscayaan, oleh karenanya kita tidak akan dapat menerima tantangan global tanpa memiliki pola pikir global. Demikian pula semestinya dalam cara dan pola pikir kita pelaku akademis dan praktisi bidang arsitektur di era tersebut. Cara berpikir seperti apa yang harus diterapkan dalam melihat peluang dan tantangan arsitektur? Yang pertama adalah melihat secara kritis hubungan dan keterkaitan arsitektur dengan latar belakang dan isu sosial, budaya, ekonomi, politik dan sebagainya. Yang kedua adalah menilai arsitektur secara obyektif dalam aspek-aspek konsep hingga teknis praktis yang semakin memudahkan masyarakat luas memahami peran arsitektur dalam kehidupan.

Tulisan ini dimaksudkan untuk melihat peluang dan tantangan arsitektur di era SDGs-2030 ini. Salah satunya dengan pendekatan keterkaitan dan hubungan arsitektur dan budaya. Salah satu alasan eksternal adalah baru di era SDGs-2030 inilah budaya mendapatkan pengakuan dan tempat sebagai penentu perubahan dunia (UNESCO, 2019).

Alasan berikutnya adalah sebuah upaya mengeksplor isu arsitektur dalam 17 target SDGs-2030, khususnya dalam indikator tematik budaya. Sebagai ilustrasi adalah sejumlah besar komunitas akademis dan praktisi arsitektur yang memasukkan visi sustainability atau keberlanjutan dalam kegiatan berarsitektur. Intensitas yang meningkat dalam 5 tahun terakhir pada ruang diskusi akademis dalam topik-topik sustainable architecture. Demikian pula industri jasa arsitektur dan konstruksi yang mengusung sustainable brand dalam produk-produk mereka. Dalam kedua contoh tersebut tema-tema teknologi sangat dominan dalam balutan tema umum sustainability. Asumsi dalam tulisan ini adalah masih sangat sedikit tema-tema budaya dan arsitektur eksplisit sebagai judul dominan dalam tema umum sustainability. Dengan demikian tulisan ini sekaligus dapat memperkaya tema-tema budaya dalam riset arsitektur terutama dalam mission research. 


\section{STUDI LITERATUR}

\section{Budaya dan Pembangunan Berkelanjutan}

Agenda SDGs-2030 (lebih lanjut disebut sebagai Agenda 2030) untuk Pembangunan Berkelanjutan adalah rencana aksi untuk manusia, planet dan kemakmuran yang diadopsi pada September 2015 oleh komunitas internasional dan menguraikan visi untuk masa depan yang lebih berkelanjutan. Agenda menyerukan kepada semua negara, selama periode lima belas tahun, untuk memobilisasi upaya untuk mengakhiri semua bentuk kemiskinan, memerangi ketidaksetaraan dan mengatasi perubahan iklim, sambil memastikan bahwa tidak ada yang tertinggal.

Agenda 2030 disusun sekitar 17 Tujuan Pembangunan Berkelanjutan (SDGs) dan 169 Target yang terhubung dengan tujuan-tujuan ini yang menyediakan kerangka kerja untuk desain dan implementasi kebijakan di tingkat lokal, nasional dan internasional. 17 SDG yang mencerminkan dimensi ekonomi, sosial dan lingkungan dari keberlanjutan (manusia, planet, dan kemakmuran), serta dua kondisi kritisnya (perdamaian dan kemitraan). Agenda 2030 dengan demikian mencerminkan pendekatan luas dan holistik untuk pembangunan berkelanjutan yang mengedepankan interdisiplinary berbagai bidang.

Poin penting dalam tulisan ini adalah mendorong visi yang berani dengan pendekatan kreatif di luar yang linier dan sektoral termasuk pendekatan luas terhadap budaya dan pembangunan. Komunitas internasional Agenda 2030, telah mengakui untuk pertama kalinya peran budaya dalam pembangunan berkelanjutan. Agenda 2030 secara implisit merujuk pada budaya di banyak tujuan dan sasarannya. Agenda 2030 mencerminkan pandangan luas tentang budaya yang mencakup kontribusi budaya terhadap pembangunan berkelanjutan termasuk melalui warisan budaya, industri kreatif, budaya dan produk lokal, kreativitas dan inovasi, komunitas lokal, bahan-bahan lokal, dan keanekaragaman budaya.

Proyek-proyek pembangunan telah menunjukkan pentingnya pengetahuan lokal dan partisipasi masyarakat untuk mencapai pembangunan berkelanjutan dari kesehatan ke pendidikan. Kontribusi budaya transversal dalam Agenda 2030 berkontribusi baik sebagai sektor kegiatan itu sendiri maupun sebagai komponen intrinsik yang ada di sektor lain. Sementara kegiatan promosi budaya selain mewakili tujuannya sendiri, ia juga berkontribusi secara transversal ke banyak Agenda 2030. UNESCO mencatat kontribusi berbagai kegiatan sektor kota yang berkelanjutan, pekerjaan yang layak dan pertumbuhan ekonomi, mengurangi ketidaksetaraan, lingkungan, mempromosikan kesetaraan jender, inovasi dan masyarakat yang damai dan inklusif. Artinya adalah bahwa peran budaya sebagai pendorong yang berkontribusi langsung untuk menghasilkan manfaat ekonomi dan sosial, dan juga sebagai enabler (sesuatu yang menjadikan menjadi mungkin) yang berkontribusi pada efektivitas intervensi pembangunan.

Pendekatan semacam itu juga menekankan pentingnya proses berkelanjutan yang mengarah pada pencapaian sasaran serta pendekatan yang menghubungkan lintas sektor, bergerak serentak menuju pencapaian berbagai daripada melihat dalam lingkup sempit yang diukur hanya dengan indikator statistik sendiri-sendiri. Pada 
gilirannya, dimensi ekonomi, sosial, dan lingkungan dari pembangunan berkelanjutan berkontribusi untuk mempromosikan pelestarian warisan budaya dan memelihara kreativitas. Selain itu, beberapa sasaran, seperti pendidikan juga menjadi tujuan pembangunan manusia yang dapat dicapai secara lebih efektif dengan budaya. Pada intinya budaya berkontribusi secara transversal ke masing-masing dari lima dimensi kritis pembangunan berkelanjutan yaitu: Manusia, Planet, Kemakmuran, Perdamaian, Kemitraan.

\section{Konvensi dan Program Kebudayaan UNESCO menuju Agenda 2030}

Konsep pembangunan berkelanjutan terletak pada inti dari Konvensi dan Program Kebudayaan UNESCO, yang masing-masing membawa perspektif atau fokus spesifik sejalan dengan ruang lingkup individu dan kerangka kerja konseptualnya. Dengan adopsi UNESCO telah mengembangkan Culture 2030 Indicators sebagai instrumen normatif internasional yang implementasinya sangat bergantung pada kerja sama internasional dan pengembangan kapasitas. Berisi tentang sejumlah 6 (enam) Konvensi Kebudayaan UNESCO yang berkontribusi langsung ke SDG 17 tentang Kemitraan, khususnya Target 17,9 (peningkatan kapasitas) dan 17,16 (kemitraan global). Mereka juga berkontribusi secara transversal ke SDG 5 tentang kesetaraan jender, terutama Target 5,5 tentang partisipasi dan kepemimpinan perempuan.

Konvensi dan program Kebudayaan UNESCO, Culture 2030 Indicators menawarkan sarana untuk menganalisis kontribusi budaya terhadap tujuan dan sasaran Agenda 2030 untuk Pembangunan Berkelanjutan dan meningkatkan posisi budaya dalam agenda pembangunan internasional. Pendekatan ini bertujuan untuk menunjukkan nilai tambah budaya untuk mengatasi tantangan global seperti perubahan iklim planet ini, mengurangi kemiskinan ekstrem, meningkatkan lapangan kerja dan memastikan hidup berdampingan secara damai serta untuk kesejahteraan masyarakat. Indikator-indikator tematik ini dapat berfungsi untuk meningkatkan pembuatan kebijakan di bidang budaya dan sektor kebijakan publik lainnya, dan mempromosikan kebutuhan untuk memperluas jangkauan aktor yang harus dilibatkan untuk mencapai pembangunan jangka panjang dan berkelanjutan.

Untuk mengukur dan memantau dampak budaya secara efisien terhadap pencapaian tujuan pembangunan berkelanjutan nasional dan lokal, negara dan kota harus mengandalkan sebanyak mungkin pada sumber data nasional dan lokal yang ada, serta data yang dikumpulkan oleh internasional dan nonpemerintah. organisasi, dan menilai data kualitatif dan kuantitatif. Mengingat tingkat pertumbuhan perkotaan yang luar biasa di seluruh dunia, kontribusi budaya dalam konteks perkotaan harus diukur secara independen untuk memberikan data spesifik kota yang dapat membantu memajukan peran budaya untuk pembangunan perkotaan berkelanjutan dan memperkuat sinergi antara jaringan dan program kotakota yang ada di UNESCO.

Implementasi Culture 2030 Indicators yang efektif menuntut pembangunan kapasitas statistik dan analitis lembaga terkait dan meningkatkan pemahaman peran dan kekhususan budaya, menilai dampak budaya, sebagai ikatan interdisipliner, membutuhkan kerja sama lintas lembaga dan sektor, dari pendidikan hingga 
lingkungan. Sebagai prioritas utama, kesetaraan jender harus didekati secara transversal dalam menilai kontribusi budaya pada Agenda 2030 dan harus diatasi dengan mengumpulkan data terpilah berdasarkan jenis kelamin atau dengan mengidentifikasi aspek jender dari kebijakan, undang-undang dan prosedur. Culture 2030 Indicators telah disusun sebagai alat aspirasi untuk mendukung negara dan kota dalam menilai kemajuan mereka sendiri dan mengukur dampak kebijakan mereka. Bukti perubahan dari waktu ke waktu di tempat yang sama adalah langkah mendasar dalam meningkatkan advokasi tentang peran budaya untuk pembangunan berkelanjutan dan menempatkan budaya sebagai inti dari kebijakan dan tindakan pembangunan berkelanjutan

\section{Hubungan Kebudayaan, Manusia dan}

\section{Arsitektur}

Arsitektur sebagai cerminan budaya manusia (Nuryanto, 2010). Arsitektur sebagai budaya material tidak hanya sekedar menyusun elemen-elemen material bangunan menjadi bangunan secara utuh, akan tetapi arsitektur juga berperan pada pembentukan ruangruang sosial dan simbolik. Ruang menjadi cerminan dari perancang dan masyarakat yang tinggal di dalamnya. Arsitektur tidak pernah netral namun selalu berhubungan dengan pengguna, budaya, serta konstruksi sosial yang ada dalam suatu masyarakat. Contohnya adalah perkembangan gagasan studi tentang indigenous architecture (arsitektur tradisional, arsitektur rakyat, arsitektur asli masyarakat) yang menunjukkan arsitektur sebagai hasil karya budaya masyarakat asli. Studi-studi semacam itu tidak hanya akan terbatas pada beberapa daerah yang mempunyai budaya asli saja, akan tetapi seluruh dunia dan pada seluruh kalangan.

Contoh lain adalah arsitek Le Corbusier sebagai seorang pelopor arsitektur modern. Gagasannya tentang " $A$ bouse is a Macbine to live in" mendobrak seluruh dunia dengan jargon fungsionalismenya (segala sesuatu akan tampak indah jika berfungsi dengan baik). Ilustrasi tersebut menyampaikan pesan gagasan arsitektur menunjukkan adanya perilaku dan sistem sosial yang dianut oleh tokoh atau masyarakat berpotensi menjadi agen perubahan.

\section{Arsitektur dan Perubahan Kebudayaan Manusia}

Sebagaimana aspek budaya yang lain, arsitektur senantiasa berubah dan mengalami evolusi sepanjang masa. Tidak perlu kita ragukan lagi, modernisme telah menjadi warna dominan produk-produk arsitektur di abad 20-21 ini. Arsitektur merupakan proses dan produk yang tangible yang mudah dikenali bentuk, pola dan perubahannya.

Perubahan yang terjadi seringkali tidak dipandang sebagai sebuah keniscayaan keberagaman namun bahkan menciptakan iklim dikotomi pada beberapa kali lini masa yang seharusnya tidak perlu dipersoalkan. Sebagai misal pada era 1990an terjadi dominasi bangunan-bangunan international style yang menafikan regional culture masing-masing. Juga dikotomi budaya tinggi dan budaya masyarakat. Budaya tinggi (High Culture) dalam arsitektur diwakili oleh bangunanbangunan, seperti monumen-sebagai bangunan tradisi desain yang agung-yang merupakan representasi dari kekuasaan dan kejeniusan individual sang arsitek. 
Sebaliknya budaya masyarakat (Folk. Culture) merupakan ekspresi yang berhubungan dengan budaya mayoritas, tanpa adanya seorang desainer, seniman atau arsitek. Diperlukan kearifan dengan tetap berpegang pada keyakinan bahwa Arsitektur menjadi agen perubahan budaya.

\section{Arsitektur dan Ekonomi Kreatif}

Ekonomi kreatif ibarat sebuah ekosistem yang merepresentasikan saling ketergantungan antara rantai nilai kreatif (creative value chain); lingkungan pengembangan (nurturance environment); pasar (market) dan pengarsipan (archiving) (Kemenparekraf, 2014). Ekonomi kreatif merupakan spektrum yang luas dari industri kreatif yang meliputi, komponen penting dari pertumbuhan perekonomian, lapangan kerja dan perdagangan internasional di era global saat ini. Sementara istilah industri kreatif itu sendiri muncul dan digunakan pertama kali tahun 1990 untuk menggambarkan semua industri berdasarkan kreativitas yang dihasilkan kekayaan intelektual. (Higgs, P. \& Cunningham, S., 2008; Henry, 2009)

Ekonomi kreatif tidak hanya terkait dengan penciptaan nilai tambah secara ekonomi, tetapi juga penciptaan nilai tambah secara sosial, budaya dan lingkungan. Dari sisi budaya, arsitektur mampu menunjukkan karakter budaya bangsa Indonesia yang beraneka ragam. Dari sisi pembangunan, jelas arsitektur berperan dalam perancangan pembangunan. Sementara ekonomi kreatif merupakan kegiatan ekonomi yang menjadikan kreativitas sebagai modal utama dalam menciptakan nilai tambah ekonomi (Gaunt F., 2015). Arsitektur sebagai salah satu subsektor ekonomi kreatif memiliki peranan yang penting dari sisi kebudayaan dan pembangunan. Saat ini pemerintah Indonesia melalui institusi Bekraf telah menyusun model pengembangan ekonomi yang mampu meningkatkan daya saing, juga dapat meningkatkan kualitas hidup Bangsa Indonesia.

Dalam Cetak Biru Pengembangan Ekonomi Kreatif Nasional (2008) ekonomi kreatif diartikan sebagai era baru ekonomi setelah ekonomi pertanian, ekonomi industri, dan ekonomi informasi yang telah berjalan sebelumnya. Lebih lanjut ekonomi kreatif diartikan sebagai kegiatan ekonomi yang mengintensifkan informasi dan kreativitas dengan mengandalkan ide dan pengetahuan dari sumber daya manusia sebagai faktor produksi utama dalam kegiatan ekonominya.

Menurut Badan Ekonomi Kreatif (Bekraf) Arsitektur termasuk dalam 16 subsektor industri kreatif disamping Aplikasi dan pengembangan permainan, Desain Produk, Fesyen, Desain Interior, Desain Komunikasi Visual, Seni Pertunjukan, Film, Animasi dan Video, Fotografi, Kriya, Kuliner, Musik, Penerbitan, Periklanan, Seni rupa dan Televisi dan Radio. Hal ini semakin menegaskan bahwa arsitektur tidak pernah netral namun selalu berhubungan dengan pengguna, budaya, serta konstruksi sosial yang ada dalam suatu masyarakat. (Prasetya R.D., 2013; Suparmin, 2017)

\section{METODE PENELITIAN}

Tulisan ini bertujuan menyampaikan eksistensi peluang dan tantangan arsitektur di era SDGs-2030. Strategi yang dilakukan adalah membaca peluang dalam isu-isu utama Agenda 2030 yang salah satunya adalah tema 
budaya. Penelitian yang mendukung tulisan ini bersifat deskriptif eksploratif. Sejumlah 22 poin indikator dalam tema budaya yang terdapat pada 4 isu utama Agenda 2030 digunakan sebagai alat utama analisis. Sementara itu klasifikasi bidang atau kegiatan arsitektur diperlukan untuk melihat bobot peluang dan tantangan yang berbeda-beda. Analisis dilakukan secara interpretatif terhadap setiap indikator dalam keterkaitannya dengan setiap klas kegiatan arsitektur.

Tabel 1. Indikator dalam Culture 2030 Indicators

\begin{tabular}{|l|l|}
\hline DIMENSION & \multicolumn{1}{c|}{ INDICATOR } \\
\hline \multirow{4}{*}{ Environment } & 1 Expenditure on heritage \\
\cline { 2 - 2 } \& Resilience & 2 Sustainable Management of heritage \\
\cline { 2 - 2 } & 3 Climate adaptation \& resilience \\
\cline { 2 - 2 } & 4 Cultural facilities \\
\cline { 2 - 2 } & 5 Open space for culture \\
\hline
\end{tabular}

\begin{tabular}{|c|c|}
\hline \multirow{7}{*}{$\begin{array}{l}\text { Prosperity \& } \\
\text { Livelihoods }\end{array}$} & 6 Culture in GDP \\
\hline & 7 Cultural Employment \\
\hline & 8 Cultural Businesses \\
\hline & 9 Household expenditure \\
\hline & 10 Trade in cultural goods \& services \\
\hline & 11 Public finance for culture \\
\hline & 12 Governance of culture \\
\hline \multirow{5}{*}{$\begin{array}{l}\text { Knowledge \& } \\
\text { Skills }\end{array}$} & $\begin{array}{l}13 \text { Education for Sustainable } \\
\text { Development }\end{array}$ \\
\hline & 14 Cultural knowledge \\
\hline & 15 Multilingual education \\
\hline & 16 Cultural \& artistic education \\
\hline & 17 Cultural training \\
\hline \multirow{5}{*}{$\begin{array}{l}\text { Inclusion \& } \\
\text { Participation }\end{array}$} & 18 Culture for social cohesion \\
\hline & 19 Artistic freedom \\
\hline & 20 Access to culture \\
\hline & 21 Cultural participation \\
\hline & 22 Participatory processes \\
\hline
\end{tabular}

\section{HASIL DAN PEMBAHASAN}

Tabel 2. Analisis Keterkaitan Bidang Arsitektur dengan Indikator Budaya Agenda 2030

\begin{tabular}{|c|c|c|c|c|c|c|c|}
\hline \multirow[t]{2}{*}{ DIMENSION } & \multirow[t]{2}{*}{ INDICATOR } & \multicolumn{3}{|c|}{$\begin{array}{l}\text { Keterkaitan Arsitektur } \\
\text { Bidang Akademis }\end{array}$} & \multicolumn{3}{|c|}{$\begin{array}{l}\text { Keterkaitan Arsitektur } \\
\text { Bidang Praktis }\end{array}$} \\
\hline & & Tinggi & Sedang & Rendah & Tinggi & Sedang & Rendah \\
\hline \multirow{5}{*}{$\begin{array}{l}\text { Environment } \\
\text { \& Resilience }\end{array}$} & 1 Expenditure on heritage & & & & & & \\
\hline & $\begin{array}{l}2 \text { Sustainable Management of } \\
\text { heritage }\end{array}$ & & & & & & \\
\hline & 3 Climate adaptation \& resilience & & & & & & \\
\hline & 4 Cultural facilities & & & & & & \\
\hline & 5 Open space for culture & & & & & & \\
\hline \multirow{5}{*}{$\begin{array}{l}\text { Prosperity \& } \\
\text { Livelihoods }\end{array}$} & 6 Culture in GDP & & & & & & \\
\hline & 7 Cultural Employment & & & & & & \\
\hline & 8 Cultural Businesses & & & & & & \\
\hline & 9 Household expenditure & & & & & & \\
\hline & 10 Trade in cultural goods \& services & & & & & & \\
\hline
\end{tabular}




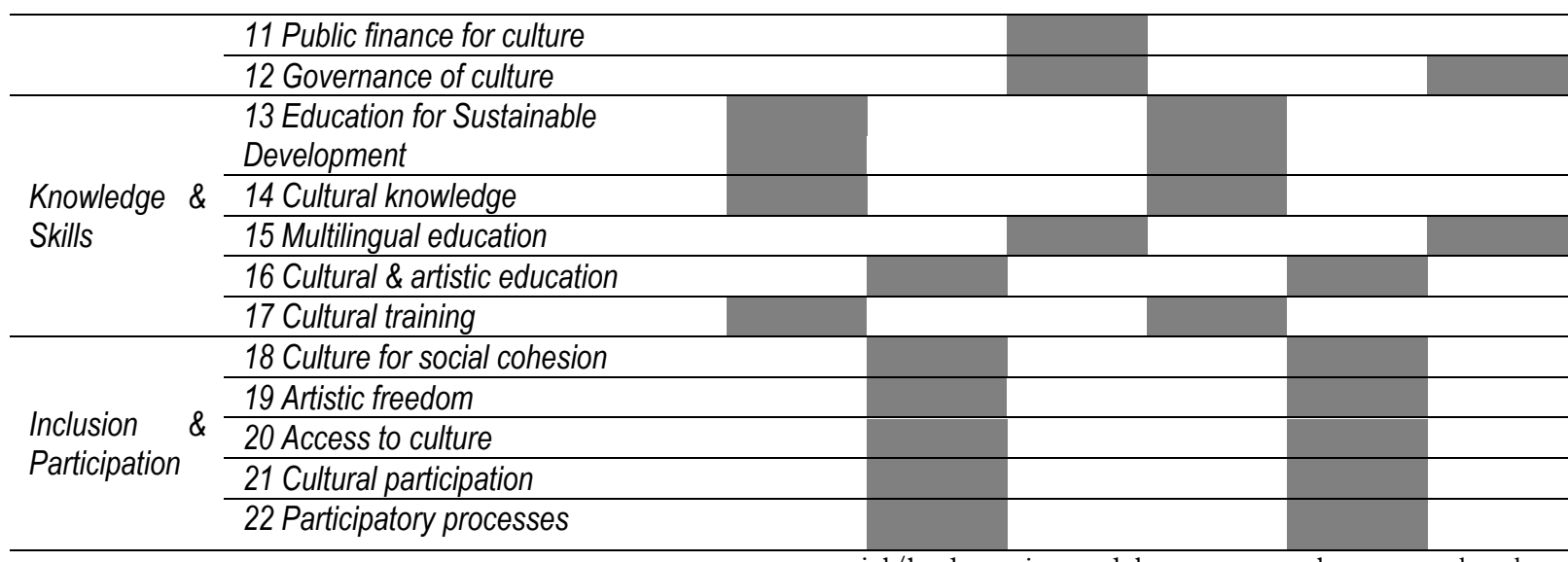

\section{Peluang dan Tantangan pada Dimensi Lingkungan dan Ketahanan (Environment \& Resilience)}

Keterkaitan tinggi pada indikator (2) pengelolaan dan perlindungan warisan budaya dan alam, praktik, pengetahuan, dan artefak historis. Peluang pada kegiatan-kegiatan pendataan dan identifikasi kegiatan di tingkat nasional dan perkotaan. Keterkaitan tinggi pada Indikator (3) mitigasi dan adaptasi perubahan iklim dan meningkatkan ketahanan melalui pelestarian berkelanjutan dan pengelolaan warisan budaya berwujud, tidak berwujud. Peluang tinggi pada bidang akademis maupun praktis antara lain dalam praktik penerapan konstruksi baru di daerah bersejarah mengacu pada keberlanjutan, teknik dan bahan bangunan alami, dan tradisional.

Keterkaitan tinggi pada indikator (4) Otoritas lokal dan nasional dalam membangun keragaman dan distribusi spasial fasilitas budaya untuk memastikan promosi ekspresi budaya yang berasal dari kelompok sosial/budaya juga dalam memperluas mereka ke berbagai kemungkinan profesional budaya dan bisnis. Keterkaitan tinggi pada indikator (5) Upaya mewujudkan ruang publik di tingkat kota yang mencakup ukuran, jumlah, distribusi dan penggunaan ruang, sebagai cara untuk menjamin kesetaraan akses dan keanekaragaman kehidupan budaya.

\section{Peluang dan Tantangan pada Dimensi Kemakmuran dan Mata Pencaharian (Prosperity \& Livelihoods)}

Keterkaitan rendah pada indikator (6), (7), (9), (11) dan (12). Arsitektur bidang akademis dan praktis tidak terkait langsung atau rendah dengan pengembangan potensi budaya untuk berkontribusi pada pendapatan nasional juga mata pencaharian dan pekerjaan. Juga tidak terkait erat dengan kegiatan penilaian ukuran pasar lokal untuk kegiatan budaya, barang, dan jasa dan untuk menginformasikan kebijakan budaya yang dapat mendorong inklusi sosial yang lebih besar melalui kegiatan budaya. Arsitektur tidak terkait langsung dengan pengeluaran publik, leverage uang publik dalam 
menciptakan lapangan kerja dan ekspresi budaya masyarakat setempat.

Keterkaitan sedang pada indikator (8) yang berhubungan dengan pola perubahan dalam sifat bisnis barang budaya dan jasa budaya karena permintaan internasional untuk barang dan jasa budaya memberikan wawasan dan kegiatan mempromosikan ekspor. Arsitektur dapat memberikan warna dan karakter bisnis budaya.

\section{Pengetahuan dan Ketrampilan (Knowledge $\&$ Skills)}

Pada dasarnya arsitektur sangat dekat dengan kegiatan pendidikan dan kebudayaan. Keterkaitan tinggi pada poin (13 dan (14) baik secara akademis maupun praktis. Arsitektur sangat berperan dalam kegiatan pendidikan dan pelatihan guna mendukung integrasi, transmisi dan promosi pengetahuan dan keterampilan budaya di bidang kreatif serta apresiasi terhadap keanekaragaman budaya dan pelatihan budaya. Arsitektur berpeluang besar dalam mempromosikan praktik budaya dan keragaman dalam kurikulum pendidikan, mendorong multibahasa, serta pendidikan seni dan budaya, meningkatkan pembelajaran dan mempromosikan apresiasi terhadap pluralisme budaya. Keterkaitan tinggi dengan indikator (17) yang berhubungan dengan kebutuhan sarana dan prasarana tempat budaya dalam Pendidikan dan Pelatihan Teknis dan Kejuruan serta pendidikan non-formal.

Keterkaitan rendah pada indikator (15) apabila dilihat dari aspek kurikulum pendidikan dan pengembangan multibahasa dalam pendidikan dasar dan menengah. Namun tetap berpeluang dalam promosi atau dialog antar budaya dan pemahaman tentang keanekaragaman budaya. Keterkaitan sedang pada indikator (16) yang mendukung pengembangan budaya dan kreatifitas keanekaragaman ekspresi budaya..

Inklusi dan Partisipasi (Inclusion \& Participation) Indikator pada isu ini mengindikasikan kepentingan yang sangat tinggi atas partisipasi, inklusi dan kohesi sosial kepada akses fasilitas budaya, hak untuk berpartisipasi dalam dan mempraktikkan ekspresi budaya, dan penyediaan lingkungan yang memelihara dan memungkinkan terjadinya kebebasan artistik, dan keragaman budaya. Indikator ini mendorong secara penuh keterlibatan efektif masyarakat lokal dalam kehidupan publik, yang pada gilirannya, mempromosikan kohesi sosial, pemahaman budaya dan membuat masyarakat yang lebih aman. Dalam kerangka tersebut keterkaitannya dengan arsitektur dalam kategori sedang ke arah kecenderungan tinggi untuk indikator (20) yang berhubungan dengan kegiatan penciptaan akses inklusid terhadap fasilitas budaya. Sementara untuk indikator lainnya (18), (19), (21) dan (22) dalam kategori sedang ke arah kecenderungan rendah karena lebih terkait dengan penciptaan kebijakan dan peraturan, partisipasi langsung dalam proses pengambilan keputusan kegiatan budaya baik secara nasional maupun di tingkat lokal. 


\section{KESIMPULAN}

- Konvensi internasional dalam Culture 2030 Indicators dapat dibaca sebagai peluang peran Arsitektur dalam era SDGs 2030 melalui tema budaya, dengan mempertimbangkan premis bahwa arsitektur dapat menjadi agen perubahan budaya.

- Arsitektur memiliki peluang dan tantangan besar dalam Agenda 2030 pada budaya di banyak tujuan dan sasaran yang mencerminkan pandangan luas tentang budaya yang mencakup kontribusi budaya terhadap pembangunan berkelanjutan termasuk melalui warisan budaya, industri kreatif, budaya dan produk lokal, kreativitas dan inovasi, komunitas lokal, bahan-bahan lokal, dan keanekaragaman budaya.

- Arsitektur memiliki keterkaitan peluang dan tantangan tinggi pada isu dimensi Lingkungan dan Ketahanan yang meliputi indikator-indikator pengelolaan dan perlindungan warisan budaya dan alam, praktik, pengetahuan, dan artefak historis. Selain itu juga dengan indikator mitigasi dan adaptasi perubahan iklim dan peningkatkan ketahanan melalui pelestarian berkelanjutan dan pengelolaan warisan budaya berwujud, tidak berwujud.

- Arsitektur memiliki keterkaitan peluang dan tantangan yang tinggi baik secara akademis dan praktis pada isu dimensi Pengetahuan dan Ketrampilan. Arsitektur sangat berperan dalam kegiatan pendidikan dan pelatihan guna mendukung integrasi, transmisi dan promosi pengetahuan dan keterampilan budaya di bidang kreatif serta apresiasi terhadap keanekaragaman budaya dan pelatihan budaya.

\section{REFERENSI}

Gaunt, F. 2015. Analisis Terbadap Para Pekerja Industri Kreatif di Kota Bandung. Laporan Skripsi rogram West Java Field Study Research dari The Australian Consortium for 'In Country Indonsian Studies (ACICIS), Universitas Parahyangan.

Henry, C. 2009. Women and the Creative Industries: Exploring the Popular Appeal. Creative Industries Journal, 2 (2), 14360.

Higgs, P. \& Cunningham, S. 2008. Creative Industries Mapping: Where have We Come from and Where are We Going?.Creative Industries Journal.1 (1), 730.

UNESCO. 2019. Thematic Indicators for Culture in the 2030 Agenda. United Nations Educational, Scientific and Cultural Organization.

Nuryanto. 2010. Hubungan Arsitektur dan Budaya. Bahan Ajar Arsitektur Vernakular Jurusan Arsitektur FPTK UPI.

Prasetya, R.D. 2013. Peran Aktif Desainer Interior dalam Pengembangan Industri Kreatif. Jurnal Lintas Ruang Vol.3, No.1, p 21-27.

Suparmin, S., Roniwijaya, P., Priyanto, S., Rahmat B., \& Setiadi. 2017. Eksplorasi Sub-sub Sektor Industri Kreatif di Pusat-pusat Keramaian Kabupaten Kulon Progo. Prosiding Seminar Nasional Multidisiplin Ilmu \& Call for Paper UNISBANK ke-3 (Sendi U-3) 